ISSN 0258-7122

Bangladesh J. Agril. Res. 38(2): 363-371, June 2013

\title{
DEGRADATION OF SOIL PROPERTIES UNDER GINGER, TURMERIC, AROID, AND JHUM RICE CULTIVATION IN HILLY AREAS OF BANGLADESH
}

\author{
N. SALAHIN ${ }^{1}$, R. A. BEGUM ${ }^{2}$, S. HOSSAIN ${ }^{3}$ \\ M. M. UlLAH ${ }^{4}$ AND M. K. ALAM ${ }^{1}$
}

\begin{abstract}
An experiment was conducted in Hill Agricultural Research Station (HARS), Khagrachari during 2011-2012 to estimate the soil loss and changes in soil properties under indigenous cultivation methods of ginger, turmeric, aroid, and jhum rice in hill slopes. The use of indigenous cultivation methods for growing different crops has created negative impact on soil productivity in hill slope. Among the four crops, the annually highest soil loss (22.68 t/ha) occurred by ginger cultivation which was statistically similar with turmeric (16.52 t/ha) followed by aroid (12.02 t/ha) and lowest soil loss (7.92 t/ha) occurred by jhum rice cultivation. There were no significant changes in soil physical properties like soil texture, bulk density, soil moisture content, field capacity. Organic matter and all the nutrients were higher in eroded soil than the post-harvested soil. A considerable amount of organic matter along with macro and micronutrients has been depleted through traditional method of crop cultivation.
\end{abstract}

Keywords: Hill soil, crop cultivation, soil erosion, soil properties.

\section{Introduction}

The conservation of soil and water is essential for sustainable production, environmental preservation, and balanced ecosystem. Loss of soil by water erosion on slopping lands adversely affects physical, chemical, and biological properties of soils leading to low crop productivity. Land use change associated erosion is mostly responsible for land degradation and desertification in different parts of Asia and Africa, bringing about large reduction in vegetation growth, siltation of water sources, filling of valleys and reservoirs and the formation of deltas along the coastal areas. Erosion is accompanied by deposition of alluvial materials by flooding and filling of valleys, waterways or extending coastal plains and deltas towards the sea.

Ginger and turmeric are perennial crops found in the tropical regions of Southern Asia. These are potential spice crops in Bangladesh and these play vital

\footnotetext{
${ }^{1}$ Scientific Officer, Soil Science Division, Bangladesh Agricultural Research Institute (BARI), Gazipur-1701, ${ }^{2}$ Chief Scientific Officer, Soil Science Division, BARI, Gazipur1701, ${ }^{3}$ Scientific Officer, Hill Agricultural Research Station, BARI, Khagrachari, ${ }^{4}$ Principal Scientific Officer, Hill Agricultural Research Station, BARI, Khagrachari, Bangladesh
} 
role in the national economy. These are important tropical horticultural crops, have values all over the World as spices and used in medicinal and cosmetic purposes and as dye in textile industries (Pruthi, 1976). These are intensively grown in the highland and hilly region with sandy soil. The tribal and hilly farmers also grow aroid and jhum rice in hill slopes. Extensive cultivation methods like heavy spading, earthing up, crop cultivation along with slope, slush, and burning caused soil loss from the hill slope for cultivation of different crops. The hilly people cultivate ginger, turmeric, aroid, and jhum rice along the slope land of the hill. They usually harvest the rhizome from soil by spade. Thus, soils become loose and soil erosion occurs in hilly areas that causes appreciable depletion in organic matter content resulting nutrient exhaustion in soil. Thus, hill cultivation in CHTs degrades land productivity and causes excess runoff. This accelerates soil erosion and causes flash floods. The additional effect, other than loss of the sloping land, is that soil particles from erosion move down the slope, and are deposited on the riverbed, in the adjoining basins and over flat alluvial land. Most of the lands in this area are hilly and rugged topography, no tillage along with across the planting system could be best suited for growing these crops in hilly areas as they are capable to reduce and minimize the soil erosion to a tolerable range (Van Doran et al., 1997).

The factors responsible for the loss of soil material are rainfall, land slope, slope length, vegetative cover density and management practices, etc. The most harmful factor is the farming practice, which is found in various forms prone to erosion. Every year more and more land is becoming denuded due to unplanned agricultural crop cultivation practices. The impact of high intensity rainfall was followed by run-off over greater slope length results in tremendous soil loss. IUCN (1991) reported that erosion of topsoil in the hill districts has increased, and 17 percent of the soil resources have deteriorated between 1964 and 1985 due to indigenous crop cultivation methods.

Facing the location specific, environmental friendly agricultural development challenges in CHTs, Soil Science Division, BARI, Gazipur has initiated its efforts to generate scientific information on the soil loss and changes in soil properties in hill slopes due to different crop cultivation. Therefore, to keep this point in view, the present study was undertaken with the following objectives:

1. To estimate soil loss under indigenous cultivation methods of ginger, turmeric, aroid, and jhum rice in hill slopes.

2. To compare soil loss among different crop cultivations.

3. To observe the changes in soil chemical properties. 


\section{Materials and Method}

The experiment was conducted at the Hill Agricultural Research Station, Khagrachari during 2011-2012 year to estimate the soil loss and changes in soil properties under indigenous cultivation methods of ginger, turmeric, aroid, and jhum rice in hill slopes. There were four treatments i.e. $T_{1}$ : Ginger, $T_{2}$ : Turmeric, $\mathrm{T}_{3}$ : Aroid and $\mathrm{T}_{4}$ : Jhum rice assigned in randomly complete block design with four replications. The experimental plots of $16 \mathrm{~m}^{2}$ (4 m x $4 \mathrm{~m}$ ) on gentle slope (6$16 \%)$ were selected in prepared structure. The crop varieties used in the experiment were Ginger (BARI ada 1), Turmeric (BARI holud 1), Aroid (Bilashi) and Jhum rice (Local) with corresponding spacing $50 \mathrm{~cm} \times 25 \mathrm{~cm}, 50$ $\mathrm{cm} \times 25 \mathrm{~cm}, 50 \mathrm{~cm} \times 25 \mathrm{~cm}$ and $20 \mathrm{~cm} \times 15 \mathrm{~cm}$, respectively. The chemical fertilizer $\mathrm{N}_{140} \mathrm{P}_{55} \mathrm{~K}_{115} \mathrm{~S}_{20} \mathrm{Zn}_{2} \mathrm{~kg} \mathrm{ha}^{-1}$ for ginger, $\mathrm{N}_{140} \mathrm{P}_{60} \mathrm{~K}_{120} \mathrm{~S}_{20}$ for turmeric and

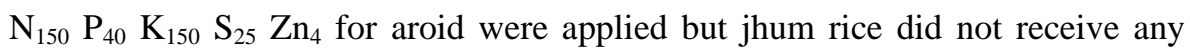
fertilizer.

Ginger and turmeric were planted on 21 May 2011, aroid on 30 May 2011 and jhum rice was sown on 1 June 2011. Among these crops, jhum rice became mature at first and harvested on 20 September 2011. Then aroid was harvested on 15 November 2011 followed by turmeric on 4 January 2012 and lastly ginger on 5 January 2012. The soil samples were collected from experimental plots at 0-15 $\mathrm{cm}$ depth before setting and after completion of the experiment and analyzed in the laboratory following standard methods. The initial results of some important soil physical and chemical properties in experimental plots have been shown in Table 1.

Different agronomic practices like weeding, earthing-up were done as usual in the plots. The crops were grown under rainfed condition. Soil loss from each experimental plot to the pre-constructed reservoir was collected three times, first time on 1 August 2011, second time on 4 January 2012 and third time on 7 May 2012. Accumulated soil in the reservoir/tank that washed out from the plots was collected and dried in oven. Rainfall data was recorded daily and month-wise presented in Table 1c. For measuring bulk density, soil samples were collected at virgin condition by core sampler. For moisture content, soil samples were collected by aluminium cup and measured by gravimetric method, soil texture by hydrometer method and field capacity by pressure plate apparatus. Chemical properties were measured in the laboratory following standard methods (Page et al., 1989). This experiment was conducted giving emphasis on soil loss but not crop performance. 
Table 1. Physical and chemical properties of initial soil $(0-15 \mathrm{~cm})$.

Table 1a. Physical properties.

\begin{tabular}{c|c|c|c|c|c|c|c}
\hline Crop & $\begin{array}{c}\text { Sand } \\
(\%)\end{array}$ & $\begin{array}{c}\text { Silt } \\
(\%)\end{array}$ & $\begin{array}{c}\text { Clay } \\
(\%)\end{array}$ & $\begin{array}{c}\text { Textural } \\
\text { Class }\end{array}$ & $\begin{array}{c}\text { Soil } \\
\text { moisture } \\
(\%)\end{array}$ & $\begin{array}{c}\text { Bulk } \\
\text { density } \\
\left(\mathrm{g} \mathrm{cm}^{-3}\right)\end{array}$ & $\begin{array}{c}\text { Field } \\
\text { capacity } \\
(\%)\end{array}$ \\
\hline Ginger & 39.36 & 27.00 & 33.64 & Clay Loam & 32.84 & 1.37 & 27.69 \\
Turmeric & 37.64 & 33.00 & 29.36 & Clay Loam & 31.79 & 1.37 & 28.12 \\
Aroid & 38.36 & 28.00 & 33.64 & Clay Loam & 33.46 & 1.40 & 26.45 \\
Rice & 37.64 & 31.00 & 31.36 & Clay Loam & 30.72 & 1.37 & 28.29 \\
\hline
\end{tabular}

Table 1b. Chemical properties.

\begin{tabular}{|c|c|c|c|c|c|c|c|c|c|c|}
\hline \multirow{2}{*}{ Crop } & \multirow{2}{*}{$\mathrm{pH}$} & \multirow{2}{*}{$\begin{array}{l}\mathrm{OM} \\
(\%)\end{array}$} & \multirow{2}{*}{\begin{tabular}{|l|}
$\begin{array}{l}\text { Total N } \\
(\%)\end{array}$ \\
\end{tabular}} & $\mathrm{P}$ & $S$ & B & $\mathrm{Zn}$ & $\mathrm{Mn}$ & K & $\mathrm{Ca}$ \\
\hline & & & & \multicolumn{5}{|c|}{$\mu \mathrm{g} \mathrm{g}^{-1}$} & \multicolumn{2}{|c|}{ meq $100 \mathrm{~g}^{-1}$} \\
\hline Ginger & 5.5 & 2.02 & 0.11 & 6.8 & 19 & 0.30 & 0.85 & 9.6 & 0.30 & 3.9 \\
\hline Turmeric & 5.4 & 1.88 & 0.09 & 6.2 & 16 & 0.25 & 0.78 & 8.7 & 0.34 & 3.8 \\
\hline Aroid & 5.1 & 2.24 & 0.12 & 6.5 & 22 & 0.22 & 0.82 & 8.3 & 0.28 & 3.7 \\
\hline Rice & 4.8 & 2.27 & 0.13 & 6.0 & 29 & 0.31 & 0.91 & 9.5 & 0.37 & 4.1 \\
\hline \multicolumn{2}{|c|}{ Critical level } & - & - & 10 & 10 & 0.20 & 0.6 & 1.0 & 0.12 & 2.0 \\
\hline
\end{tabular}

Table 1c. Rainfall data of whole growing season month wise (May, 2011- May, 2012).

\begin{tabular}{c|c}
\hline Month & Rainfall (cm) \\
\hline 22-30 May, 2011 & 9.81 \\
June, 2011 & 19.05 \\
July, 2011 & 19.86 \\
August, 2011 & 39.74 \\
September, 2011 & 17.84 \\
October, 2011 & 6.98 \\
November, 2011 & - \\
December, 2011 & - \\
January, 2012 & - \\
February, 2012 & - \\
March, 2012 & 9.10 \\
April, 2012 & 19.55 \\
May, (1-7 May), 2012 & 1.14 \\
\hline Total & 163.07 \\
\hline
\end{tabular}




\section{Results and Discussion}

\section{Physical properties of hilly soils}

The physical properties of the post harvest soil samples have been shown in Table 2a. There were no substantial changes in soil physical properties. The post harvest soil in experimental plots showed silt and clay percentage slightly decreased than initial soil. This is due to wash out of surface silt and clay properties with sediments from experimental plots to reservoirs for rainfall in growing season. The soil texture of experimental plot was unchanged, which was clay loam and the soil moisture content ranged from 32.46 to $34.25 \%$ in the $15 \mathrm{~cm}$ topsoil layer (Table 2a). There were no significant differences of bulk density among the crop treatments that ranged from 1.40 to $1.44 \mathrm{~g} / \mathrm{cm}^{3}$ in the $15 \mathrm{~cm}$ topsoil layer but it increased slightly than initial condition. A higher value of bulk density in post harvest soil along with decreasing trends of silt and clay indicated the slight exposure of coarser particles resulted from soil erosion. This result is very close to the findings of Boyle (1975). Field capacity ranged from 25.75 to $27.16 \%$ in the $15 \mathrm{~cm}$ topsoil layer and no significant variation was found between initial and post harvest result (Table 2a).

Table 2a. Physical properties of post harvest soils $(0-15 \mathrm{~cm})$ in experimental plots.

\begin{tabular}{c|c|c|c|c|c|c|c}
\hline Crop & $\begin{array}{c}\text { Sand } \\
(\%)\end{array}$ & $\begin{array}{c}\text { Silt } \\
(\%)\end{array}$ & $\begin{array}{c}\text { Clay } \\
(\%)\end{array}$ & $\begin{array}{c}\text { Textural } \\
\text { Class }\end{array}$ & $\begin{array}{c}\text { Soil } \\
\text { moisture } \\
(\%)\end{array}$ & $\begin{array}{c}\text { Bulk } \\
\text { density } \\
\left(\mathrm{g} \mathrm{cm}^{-3}\right)\end{array}$ & $\begin{array}{c}\text { Field } \\
\text { capacity } \\
(\%)\end{array}$ \\
\hline Ginger & 42.64 & 26.00 & 31.36 & Clay loam & 34.25 & 1.40 & 27.16 \\
Turmeric & 39.64 & 32.00 & 28.36 & Clay loam & 33.12 & 1.42 & 26.97 \\
Aroid & 40.36 & 27.00 & 32.64 & Clay Loam & 33.25 & 1.41 & 26.42 \\
Rice & 41.64 & 29.00 & 29.36 & Clay Loam & 32.46 & 1.44 & 25.75 \\
\hline
\end{tabular}

\section{Chemical properties of hilly soils}

Soils of the experimental site were acidic in nature. The $\mathrm{pH}$ ranged from 5.0 to 5.6. Traditional crop cultivation adversely affected and accelerated topsoil erosion and land degradation. Soil nutrients were lost through topsoil erosion (Table 2a).

Organic matter in experimental plot soils was lower as compared to initial soils. Organic matter of post harvest soil in experimental plot ranged from 1.50 to $1.98 \%$ in the $15 \mathrm{~cm}$ topsoil layer which was lower than initial soils (1.88$2.27 \%)$. The total nitrogen in experimental plot soils (0.07- $0.10 \%)$ was lower than that of initial soils (0.14- $0.18 \%)$. The available $\mathrm{P}$ was higher in the initial soil (6.0- $6.8 \mu \mathrm{g} / \mathrm{g})$ than post harvest soils (5.4- $5.7 \mu \mathrm{g} / \mathrm{g})$ and similar trend was observed in case of almost all nutrients. This might be because of nutrients depletion due to erosion of top soil of the experimental plots. This result is in 
agreement with the findings of many other scientists (Muhr, 1965; World Bank, 1991; Khisa et al., 2002 and Gafur et al., 2000). Thus, soil erosion along with nutrients depletion is considered as a serious problem on the sloping lands of the CHTs. Greer et al. (1996) reported that a decline in SOM (biological oxidation or erosion) significantly reduced the $\mathrm{N}$ supply and resulted in a deterioration of soil physical conditions, leading to crop yield reduction.

2b. Chemical properties of post harvest soil $(0-15 \mathrm{~cm})$ in experimental plots.

\begin{tabular}{|c|c|c|c|c|c|c|c|c|c|c|}
\hline \multirow{2}{*}{ Crop } & \multirow{2}{*}{$\mathrm{pH}$} & \multirow{2}{*}{$\begin{array}{l}\mathrm{OM} \\
(\%)\end{array}$} & \multirow{2}{*}{\begin{tabular}{|c|} 
Total N \\
$(\%)$
\end{tabular}} & $\mathrm{P}$ & $S$ & B & $\mathrm{Zn}$ & $\mathrm{Mn}$ & $\mathrm{K}$ & $\mathrm{Ca}$ \\
\hline & & & & \multicolumn{5}{|c|}{$\mu \mathrm{g} / \mathrm{g}$} & \multicolumn{2}{|c|}{ Meq/100g } \\
\hline Ginger & 5.6 & 1.75 & 0.09 & 5.7 & 15 & 0.25 & 0.64 & 8.7 & 0.27 & 3.4 \\
\hline Turmeric & 5.2 & 1.50 & 0.07 & 5.4 & 14 & 0.21 & 0.57 & 7.2 & 0.23 & 3.0 \\
\hline Aroid & 5.3 & 1.82 & 0.09 & 5.5 & 17 & 0.18 & 0.53 & 7.5 & 0.20 & 2.8 \\
\hline Rice & 5.0 & 1.98 & 0.10 & 5.6 & 18 & 0.24 & 0.74 & 8.8 & 0.28 & 3.5 \\
\hline \multicolumn{2}{|c|}{ Critical level } & - & - & 10 & 10 & 0.20 & 2.0 & 1.0 & 0.12 & 2.0 \\
\hline
\end{tabular}

The eroded top soil of the experimental plot was accumulated in the reservoir contained the higher amount of $\mathrm{OM}$ and plant nutrients as compared to both initial and experimental plot soil (Table 2c). Organic matter, total $\mathrm{N}$ and available $\mathrm{P}, \mathrm{K}, \mathrm{S}$, and micronutrients were found higher in eroded soils in the reservoir than in the initial soil as well as in post harvest experimental plot soil. Reduced OM might have led to decrease water holding capacity of soil and favoured through increased runoff (Thierfelder and Wall, 2010). Declining SOM in crop field also diminished the ability of soil to release nutrients in appropriate synchrony with crop demand (Drinkwater and Snapp, 2007). A decline in SOM results in an inevitable decline in soil biological activity as well (Soon and Arshad, 2005).

Table 2c. Chemical properties of the eroded soil in reservoirs.

\begin{tabular}{|c|c|c|c|c|c|c|c|c|c|c|}
\hline \multirow{2}{*}{ Crop } & \multirow{2}{*}{$\mathrm{pH}$} & \multirow{2}{*}{$\begin{array}{l}\mathrm{OM} \\
(\%)\end{array}$} & \multirow{2}{*}{$\begin{array}{l}\text { Total } \\
\text { N (\%) }\end{array}$} & $\mathrm{P}$ & $\mathrm{S}$ & $\mathrm{B}$ & $\mathrm{Zn}$ & $\mathrm{Mn}$ & $\mathrm{K}$ & $\mathrm{Ca}$ \\
\hline & & & & \multicolumn{5}{|c|}{$\mu \mathrm{g} / \mathrm{g}$} & \multicolumn{2}{|c|}{ Meq/100g } \\
\hline Ginger & 5.6 & 2.12 & 0.11 & 7.5 & 22 & 0.31 & 0.98 & 9.1 & 0.32 & 3.5 \\
\hline Turmeric & 5.2 & 2.09 & 0.10 & 7.1 & 24 & 0.34 & 1.24 & 8.9 & 0.29 & 3.2 \\
\hline Aroid & 5.3 & 2.41 & 0.13 & 7.8 & 27 & 0.37 & 1.36 & 9.4 & 0.25 & 3.1 \\
\hline Rice & 5.5 & 2.34 & 0.12 & 8.2 & 21 & 0.33 & 1.49 & 9.0 & 0.27 & 3.7 \\
\hline \multicolumn{2}{|c|}{ Critical level } & - & - & 10 & 10 & 0.20 & 0.6 & 1.0 & 0.12 & 2.0 \\
\hline
\end{tabular}

\section{Soil loss due to different crops cultivation}

Soil loss under different crop cultivation during 2011-2012 year is presented in Table 3. Soil loss under different crop cultivation throughout the year was 
calculated on oven dry basis. It was recorded that the highest soil loss was recorded in ginger growing plots $(22.68 \mathrm{t} / \mathrm{ha} / \mathrm{yr})$, which was statistically similar with that of turmeric plots (16.52 t/ha/yr) followed by aroid plots (12.02 t/ha/yr). The lowest soil loss was found in rice growing plots $(7.92 \mathrm{t} / \mathrm{ha} / \mathrm{yr})$. The highest soil loss occurred by ginger and turmeric cultivation because soils needed to more disturbances for making the soil more loose and softer for growing these crops, whereas, for rice cultivated soils went through minimum disturbance. These eroded soils contained higher amount of organic matter, N, P, K, S, and other micronutrients due to fertilizer application during crop cultivation.

Throughout the growing season of crops (2011-2012), a total of $163.07 \mathrm{~cm}$ rainfall occurred. This rainfall favoured the soil erosion along with continuous nutrient depletion. The process is accelerated by open indigenous cultivation system. The depleting soil fertility of hill soils becomes more serious if the faulty cultivation methods go on year after year.

The present study also correlates with the finding of LRMP (1986a) where it was reported that loss of topsoil has affected the soil fertility and the inherent productivity of soil through loss of nutrients and degradation of soil physical structure. A study in Khagrachari, Rangamati and Bandarban area on topsoil erosion revealed that topsoil erosion ranged from 100 to 120 tons per ha annually (Farid et al., 1992).

Table 3. Average soil loss under the cultivation of different crops in 2011-2012.

\begin{tabular}{cc}
\hline Crop & Average soil loss (t/ha/yr, oven dry basis) \\
\hline Ginger & $22.68 \mathrm{a}$ \\
Turmeric & $16.52 \mathrm{ab}$ \\
Aroid & $12.02 \mathrm{~b}$ \\
Rice & $7.92 \mathrm{~b}$ \\
\hline Level of significance & $*$ \\
CV $(\%)$ & 39.06 \\
\hline
\end{tabular}

\section{Crop yield}

Maximum yield was found from turmeric (7.29 t/ha) followed by aroid (5.53 $\mathrm{t} / \mathrm{ha})$, ginger (3.58 $\mathrm{t} / \mathrm{ha})$, and jhum rice $(0.50 \mathrm{t} / \mathrm{ha})$ at $6-16 \%$ hill slope across the slope arrangement. The yield of jhum rice was very low due to lack of soil moisture at tillering stage. Present results are also consistent with the findings of Salahin et al. (2010) who showed that soil moisture is the major constraint in hilly areas for crop cultivation. This experiment was conducted as like as hilly farmers of Bangladesh who generally cultivate their crops under rainfed condition. The ginger yield was also low due to infestation by rhizome rot disease at pre-mature stage. 
Table 5. Performance of crops at hill slopes.

\begin{tabular}{cc}
\hline Crops & Yield (t/ha) \\
\hline Ginger & 3.58 \\
Turmeric & 7.29 \\
Aroid & 5.53 \\
Rice & 0.50 \\
\hline
\end{tabular}

\section{Conclusions and Recommendation}

From the study, it can be concluded that the use of indigenous cultivation methods for growing different crops created negative impact on soil loss in hill slope. Among the four crops, annually highest soil loss (22.68 t/ha) occurred by ginger cultivation, which was statistically similar with turmeric (16.52 t/ha) followed by aroid (12.02 t/ha) and lowest soil loss (7.92 t/ha) occurred by jhum rice cultivation. There were no significant changes in soil physical properties like soil texture, bulk density, soil moisture content, field capacity, but chemical properties like SOM content, macro and micronutrients showed a considerable depletion in experimental plots. As erosion is a natural process, it can not be entirely prevented; but it must be limiting to a tolerable rate following across the slope cultivation with minimal soil disturbance up to 15- 20\% hill slope.

\section{References}

Boyle, J. R. 1975. Whole tree harvesting impact on site quality. Paper presented at the Tappi Annual Meeting, 24-26 February. New York.

Drinkwater, L. E. and S. S. Snapp. 2007. Nutrients in agroecosystems: rethinking the management paradigm. Adv. Agron. 92: 163-186.

Farid, A. T. M., A. Iqbal and Z. Karim. 1992. Soil Erosion in the Chittagong Hill Tracts and Its Impact on Nutrient Status of Soils, Bangladesh Journal of Soil Science 23(1\&2): 92-101.

Gafur, A., O. K. Borggaard, J. R. Jensen and L. Petersen. 2000. Changes in soil nutrient content under shifting cultivation in the Chittagong Hill Tracts of Bangladesh. Danish J. Geogr. 100: 37-46.

Greer, K.J., D. W. Anderson and J. J. Schoenau. 1996. Soil erosion, organic matter decline and soil quality indicators. P. 21-33. In G. M. Coen and H. S. Vanderpluym (ed.) Proc. of Soil Quality Assessment for the Prairies Workshop, Edmonton, Alberta.

IUCN. 1991. National Conservation Strategy of Bangladesh (Draft), International Union for Conservation of Nature and Natural Resources; Ministry of Environment and Forest. GoB, Dhaka, Bangladesh. P. 83.

Khisha, S. K., J. U. M. Shoaib and N. A. Khan. 2002. The experience of promoting slope agricultural land technology for hillside farms in the Chittagong Hill Tracts. In: 
"Farming Practices and Sustainable Development in the Chittagong Hill Tract" (N.A. Khan et al., Eds.). CHTDB and VFFP, Interco-operation, Pp. 114-115.

LRMP. 1986a. Land Utilization Report. Land Resource Mapping Project, HMG/Nepal.

Muhr, G. R. 1965. Soil Testing in India, USAID, New Delhi, Pp. 39-41.

Page, A. L., R. H. Miller and D. R. Keeny. 1989. Methods of Soil Analysis. Part-I and Part-II. $2^{\text {nd }}$ Edn. Amer. Soc. Agron. Inc. Pub. Madison, Wilsconsin, USA.

Pruthi, J. S. 1976. Spices and condiments National Bank Trust, New Delhi, India. 226.

Salahin, N., R. A. Begum, M. S. Islam, M. M. Ullah and M. K. Alam. 2011. Investigation on soil properties in relation to crop production in Chittagong Hill Tracts. Bangladesh J. Agri. 36 (2): 81-85.

Soon, Y. K. and M. A. Arshad. 2005. Tillage and liming effects on crop and labile soil nitrogen in an acid soil. Soil and Tillage Research 105: 217-227.

Theirfelder, C. and P. C. Wall. 2010. Rotations in conservation agriculture systems of Zambia: effects on soil quality and water relations. Exp.Agric. 46: 1-17.

Van Doran, D. H. Jr., G. B. Triplett and J. E. Heury. 1997. Influence of long-term tillagecrop rotation and soil type combination on corn yield. Am. J. Soil. Sci. 40: 100-105.

World Bank. 1991. The forest sector: A World Bank Policy Paper. World Bank, Washington D. C. 